\title{
Increase in asthma: a more toxic environment or a more susceptible population?
}

\author{
Anthony Seaton, David J Godden, Katrina Brown
}

Serial prevalence studies have shown that childhood asthma is becoming more common. In the UK two recent studies have found that the overall prevalence of episodic wheeze and of diagnosed asthma has doubled over the last two decades. ${ }^{12}$ In these studies the prevalence of hay fever was also shown to have increased by a factor of three to four, while that of eczema had doubled. In children in New Zealand and Australia asthma prevalence has also doubled over the same period. ${ }^{34}$ The situation in adults is less clear, and data for the UK are not available, but most evidence from other countries suggests that a similar increase is occurring. Thus, although Yunginger et $a l^{5}$ found no evidence of an increase in the incidence of asthma in the adult population of Rochester, Minnesota during the years 196483, analysis of data from conscripts to the Finnish and Swedish defence forces reveals a sixfold increase in asthma prevalence at call-up examinations between 1966 and 1989 in Finland, ${ }^{6}$ and a $47 \%$ increase between 1971 and 1981 in Sweden. ${ }^{7}$ In Busselton, Australia ${ }^{8}$ the prevalence of diagnosed asthma in adults aged 18-55 increased from $9 \%$ to $16 \cdot 3 \%$ between 1981 and 1990, and in Manitoba, Canada, physician diagnosed asthma was found to be increasing in all age groups between 1980 and $1990 .{ }^{9}$ As well as changes over time, increases in the prevalence of asthma have also followed "westernisation" of a society ${ }^{10}$ and migration from subsistence societies to economically developed countries. ${ }^{1112}$

It is generally agreed that the observed increase in the prevalence of asthma is not simply a consequence of improved diagnosis ${ }^{1314}$ or of diagnostic transfer. ${ }^{15} \mathrm{~A}$ change in genetic susceptibility of the population to the development of asthma is unlikely in the time period over which the observed increase has occurred. A more probable explanation is that the increase is due to the effects of life in the industrialised world resulting in an increase in exposure to exogenous factors which may induce asthma, a reduction in host resistance, or a combination of both mechanisms. Among exogenous factors which have been implicated in the increase in asthma are outdoor pollutants, indoor pollutants, cigarette smoke, and allergen exposure. Factors altering host resistance have received less attention.

It has been suggested recently that a similar increase in the prevalence of hay fever coin- cided with the industrial revolution of the 18th and 19th centuries, ${ }^{16}$ and it is not surprising that the attention of researchers should have focused on air pollution - both outdoors and indoors - as a potential cause of increased asthma prevalence. With regard to outdoor pollutants, there is no doubt that many of these - including sulphur dioxide, ozone, sulphuric acid and oxides of nitrogen - can induce bronchoconstriction in susceptible individuals in the laboratory setting. ${ }^{17}$ There is epidemiological evidence from the USA ${ }^{18}$ and from the $\mathrm{UK}^{19}$ that increases in ambient photochemical oxidants may be associated with respiratory symptoms and increased bronchodilator use in asthmatic subjects. However, air pollution in general in the UK has lessened substantially since the smogs of the 1950s with reduced burning of coal in cities, and there has been a well documented fall in levels of smoke and sulphur dioxide. Ozone is primarily a rural pollutant and the limited evidence available suggests that urban levels have not altered since the early $1970 \mathrm{~s}^{20}$ There is some evidence of a rise in background levels of oxides of nitrogen in rural situations since the 1970 s, but peak urban levels in cities do not appear to have risen. ${ }^{2021}$ While these data over an adequate time and range of sites are sparse, there is no evidence of the significant rises in any pollutants that would have been necessary were they to have been responsible for the increase in asthma and hay fever. In support of this conclusion, no association between exposure to particulates, nitrogen dioxide, or sulphur dioxide and prevalence of asthma was found in the American six cities study, ${ }^{2223}$ nor in a more recent study ${ }^{24}$ which compared schoolchildren in the heavily polluted city of Leipzig and the cleaner city of Munich; there was significantly more hay fever and rhinitis in Munich children, while the prevalence of asthma and airway hyperreactivity did not differ significantly between the two populations.

The major component of indoor air pollution is cigarette smoke and there is abundant evidence that exposure to the constituents of cigarette smoke in utero and in childhood can increase the risk of developing allergy and respiratory symptoms. ${ }^{25-30}$ Again, however, it is difficult to attribute the considerable increase in asthma to changes in parental smoking. In the UK there has been a decline in the 
numbers of smokers over the last two decades. In $197233 \%$ of professional men and women, $64 \%$ of unskilled men, and $42 \%$ of unskilled women smoked. By 1988 these figures had fallen to $16 \%$ and $17 \%$, respectively, of male and female professionals, $43 \%$ of unskilled men, and $39 \%$ of unskilled women. ${ }^{31}$ This marked social gradient amongst smokers is the opposite of that seen in the distribution of asthma and hay fever in surveys of the general population..$^{32}$ It is, of course, possible that an effect of smoke exposure in utero or in early life may not manifest until later life. If this mechanism was to account for the change in asthma prevalence in 8-13 year olds between 1964 and $1989,{ }^{1}$ for example, we would expect to have observed an increased prevalence of parental smoking between the periods 1951-6 and 1976-81. Between these dates the prevalence of smoking in women aged 16-24 did indeed rise from $36 \%$ to $45 \%$, but in the $25-34$ age group it fell from $51 \%$ to $45 \%$. In men these age group prevalences fell from $56 \%$ to $45 \%$, and from $67 \%$ to $46 \%$, respectively. ${ }^{33}$ While it is possible that a $6 \%$ increase in smoking in the youngest age group of women could have contributed to the rise in prevalence of asthma these figures suggest that the main explanation may lie elsewhere.

If increased exposure to air pollution and cigarette smoke do not account for the substantial increase in prevalence of asthma and hay fever, what other factors in the environment may be responsible? Increased exposure to allergen has been suggested, with two phases of response: sensitisation in genetically predisposed individuals, and subsequent prolonged exposure leading to airway hyperreactivity. ${ }^{34-36}$ Although the case for allergen exposure leading to clinical symptoms of asthma is well established, and there are some specific examples of increases in asthma prevalence in relation to increased allergen exposure (as, for example, when the Prosopis tree was introduced to beautify Kuwait ${ }^{37}$ ), there is no direct evidence for an increase in allergen load to explain the observed increase in asthma prevalence. The two most important domestic allergen sources in the UK are house dust mites and cats. Absolute levels of house dust mite allergen in one study ${ }^{36}$ were unchanged over the period 1979-89. Furthermore, domestic beds across the range of social conditions contained large numbers of mites in the 1960 s and $1970 \mathrm{~s}^{3839}$ when asthma prevalence was lower than today. Whilst we have been unable to obtain data on numbers of household pets in the UK, we have obtained a surrogate measure from the average weekly household expenditure on pet food.$^{40}$ Corrected for inflation, these figures showed a rise in the early 1970 s but have remained at a lower level since then (fig 1); this suggests that no significant increase in population exposure to pet allergens has occurred. Thus, although it is beyond dispute that all of these inhalable factors may provoke attacks and sometimes initiate asthma, there is little overt evidence in support of the hypothesis that they are responsible, alone or

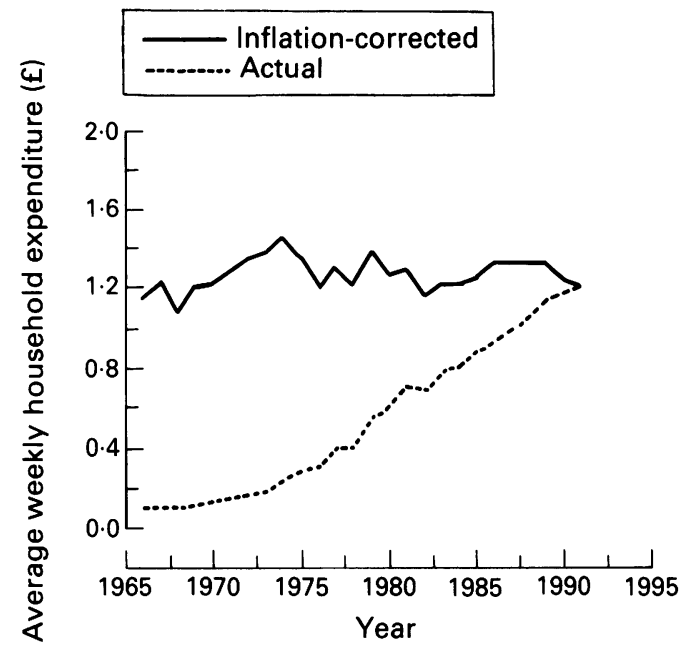

Figure 1 Average weekly household expenditure on pet food, 1961-91. Inflation-corrected expenditure is related to 1991 prices. Data are derived from reference 41.

in combination, for the substantial rise in the prevalence of atopic disease.

An alternative hypothesis is that host resistance has declined because of an alteration in diet associated with the "westernisation" of societies. There has been a substantial and well documented change in the British diet since the 1950s. Data from the National Food Surveys $^{41}$ are illustrated in fig 2 . Between 1961 and 1985 average weekly consumption of fresh fruit fell $26 \%$ from $611 \mathrm{~g}$ to $451 \mathrm{~g}$, green vegetables fell $51 \%$ from $422 \mathrm{~g}$ to $204 \mathrm{~g}$, and potatoes fell $37 \%$ from $1624 \mathrm{~g}$ to $1016 \mathrm{~g}$. These foods are the main sources of the important antioxidants vitamin $C$ and $\beta$-carotene. At the same time there have been reductions in the consumption of fresh fish and red meat which are important contributors of the antioxidant ubiquinone, and of selenium, zinc, and copper which are essential cofactors for antioxidant defence mechanisms. While detailed information on the diets of children and pregnant women is not available, it is likely that these have reflected changes in the general diet of adults over this period. Objective evidence of

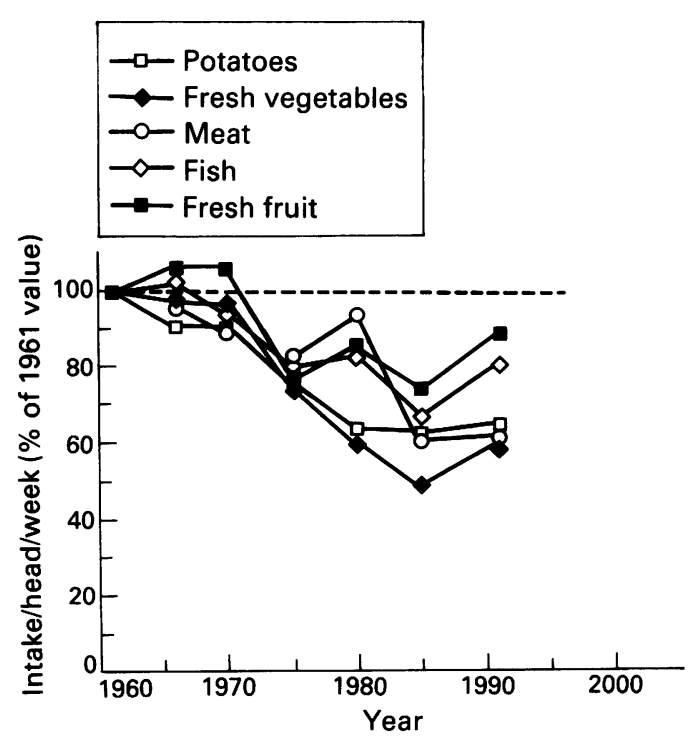

Figure 2 Mean adult weekly intake of major foods, 1961-91, expressed as percentage of 1961 levels. 
the relative deficiency of antioxidants in one area of Scotland has recently been published ${ }^{42}$ showing that more than $50 \%$ of a randomly ascertained population sample consumed less than the recommended daily intake of vitamins C, E, and carotene. Similar findings for vitamins $C$ and $E$ have been shown in a much larger Scottish population sample (10 359 subjects).$^{43}$ It is reasonable, therefore, to hypothesise that these changes in diet are responsible for the increase in asthma and rhinitis.

If this is the case, what might be the mechanism? A major characteristic of asthma, whatever its provoking cause, is airway inflammation characterised especially by the presence of eosinophils and $T$ lymphocytes in the airways. ${ }^{44}$ Such inflammation, in addition to forming one of the major clinicopathological features of asthma and rhinitis, may also increase the susceptibility of the individual to allergic sensitisation, ${ }^{45} 46$ perhaps by increasing access of antigen to submucosal $\mathrm{T}$ lymphocytes. An important mechanism in the inflammatory process is the generation of oxygen free radicals. Exposure of airways to exogenous free radicals, from cigarette smoke and air pollutants, adds to the oxidant load on these tissues promoting further inflammation. Inhalation of ozone, for example, induces airway inflammation $^{47}$ and increases lung permeability as measured by clearance of technetium$99 \mathrm{~m}$ labelled DTPA ${ }^{48}$ in non-asthmatic subjects. The lung has several natural intracellular and extracellular antioxidant defence systems ${ }^{49}$ which inhibit reactive oxidant propagation and scavenge hydroxyl radicals and singlet oxygen. Their function is dependent on nutritional antioxidants, including vitamins $\mathrm{A}, \mathrm{C}$, and $\mathrm{E} .{ }^{49}$ The dietary changes which have occurred over recent years may have led to a reduction in these natural antioxidant defences, resulting in a shift of the antioxidant status of the whole population and leading to increased susceptibility to oxidant attack and airway inflammation. This hypothesis would explain the observation that asthma and rhinitis have increased substantially, in spite of minor and sometimes apparently favourable changes in airborne pollutants and allergens. It may also explain the concurrent increase in prevalence of childhood eczema. It already has some published support in that studies have shown reduced selenium levels in subjects with asthma, ${ }^{5051}$ poorer ventilatory function in people with a reduced intake of fresh fruit and vegetables, ${ }^{52}$ and lower values for $\mathrm{FEV}_{1}$ in subjects with low levels of vitamin C intake. ${ }^{53}$ It is consistent with the observation that asthma mortality is related geographically to sales of table salt ${ }^{54}$ in that salt intake is likely to be confounded with a poor diet. The effects of supplementing antioxidant intake have not been adequately studied although two reports have described attenuation by vitamin $C$ of bronchoconstriction induced by ozone $\mathrm{e}^{55}$ and nitrogen dioxide ${ }^{56}$ in non-asthmatic subjects, and others have shown vitamin $\mathrm{C}$ to attenuate bronchial reactivity to histamine and methacholine in both non-asthmatic and asthmatic subjects. ${ }^{5758}$

Interest in environmental factors in respira- tory disease has understandably tended to focus on clearly harmful toxic substances. It is, however, unlikely that the air we breathe as infants and children has become twice as harmful, indoors or out, as it was 20 years ago. It is therefore timely to investigate whether, as a population, we have become more susceptible to respiratory disease as a consequence of dietary omission; if this turns out to be the case, the apparently relentless rise in allergic disease could be reversed relatively easily. Indeed, if the dietary hypothesis is correct, the favourable trend in eating habits between 1985 and 1991 seen in fig 2 may already be having a beneficial effect.

1 Ninan TK, Russell G. Respiratory symptoms and atopy in Aberdeen schoolchildren: evidence from two surveys 25 years apart. $B M \mathcal{F}$ 1992;304:873-5

2 Burr ML, Butland BK, King S, Vaughan Williams E. Changes in asthma prevalence: two surveys 15 years apart. Arch Dis Child 1989;64:1452-6.

3 Mitchell EA. Increasing prevalence of asthma in children. $N Z$ Med f 1983;96:463-4.

4 Robertson CF, Heycock E, Bishop J, Nolan T, Olinsky A, Phelan PD. Prevalence of asthma in Melbourne schoolchildren: changes over 26 years. BMF 1991;302:1116-8.

children: changes over 26 years. BMf $1991 ; 302: 1116-8$.
Yunginger JW, Reed CE, O'Connell EJ, Melton LJ, O'Fallon WM, Silverstein MD. A community-based study of the epidemiology of asthma. Am Rev Respir Dis 1992;146:888-94.

6 Haahtela T, Lindholm H, Bjorksten F, Koskenvuo K, Laitinen LA. Prevalence of asthma in Finnish young men. BMf 1990;301:266-8.

7 Aberg N. Asthma and allergic rhinitis in Swedish conscripts. Clin Exp Allergy 1989;19:59-63.

8 Peat JK, Haby M, Spijker J, Berry G, Woolcock AJ. Prevalence of asthma in adults in Busselton, Western Australia. $B M \mathcal{F}$ 1992;305:1326-9.

9 Manfreda J, Becker AB, Wang PZ, Roos LL, Anthonisen NR. Trends in physician-diagnosed asthma prevalence in Manitoba between 1980 and 1990. Chest 1993;103:151-7.

10 Waite DA, Eyles EF, Tonkin SL, O'Donnell TV. Asthma prevalence in Tokelauan children in two environments. Clin Allergy 1980;10:71-5.

11 Van Niekerk $\mathrm{CH}$, Weinberg EG, Shore SC, Heese HV, van Schalkwyk J. Prevalence of asthma: a comparative study of urban and rural Xhosa children. Clin Allergy of urban and

12 Woolcock AJ, Dowse G, Temple K, Stanley H, Alpers MP, Turner KJ. Prevalence of asthma in the South Fore people of Papua New Guinea. A method for field studies of bronchial reactivity. Eur $\mathcal{F}$ Respir Dis 1983;64:571-81.

13 Burney PGJ, Chinn S, Rona RJ. Has the prevalence of asthma increased in children? Evidence from the National Study of Health and Growth 1973-1986. BMF 1990;300:1306-10.

14 Britton J. Asthma's changing prevalence. $B M \mathcal{F}$ 1992;304:857-8.

15 Gergen PJ, Weiss KB. The increasing problem of asthma in the United States. Am Rev Respir Dis 1992;146:823-4.

16 Finn R. John Bostock, hay fever, and the mechanism of allergy. Lancet 1992;340:1453-5.

17 Pierson WE, Koenig JQ. Respiratory effects of air pollution on allergic disease. F Allergy Clin Immunol 1992;90:55766.

18 Whittemore AS, Korn EL. Asthma and air pollution in the Los Angeles area. Am $\mathcal{F}$ Public Health 1980;70:687-96.

19 Higgins BG, Francis HC, Warburton CJ, Yates C, Fletcher AM, Pickering CAC, et al. The effects of air pollution on ocular and respiratory symptoms in subjects with asthma and chronic bronchitis. Thorax 1993;48:417.

20 Quality of Urban Air Review Group. Urban air quality in the United Kingdom. Department of the Environment, 1992.

21 United Kingdom Photochemical Oxidants Review Group. Oxides of nitrogen in the United Kingdom. Department of the Environment, 1990.

22 Ware JH, Ferris BG, Dockery DW, Spengler JD, Stram DO, Speizer FE. Effects of ambient sulfur oxides and suspended particles on respiratory health of preadolescent suspended particles on respiratory health of preado
children. Am Rev Respir Dis 1986;133:834-42.

23 Dockery DW, Speizer FE, Stram DO, Ware JH, Spengler JD, Ferris BG Jr. Effects of inhalable particles on respiratory health of children. Am Rev Respir Dis 1989;139:58794.

24 Von Mutius E, Fritzch C, Weiland SW, Roll G, Magnussen $H$. Prevalence of asthma and allergic disorders among children in united Germany: a descriptive comparison BMF 1992;305:1395-9.

25 Magnusson CG. Maternal smoking influences cord serum $\mathrm{IgE}$ and IgD levels and increases the risk for subsequent infant allergy. $\mathcal{F}$ Allergy Clin Immunol 1986;78:898-904.

26 Andrae S, Axelson O, Bjorksten B, Fredriksson M, Kjellman N-IM. Symptoms of bronchial hyperreactivity and asthma in relation to environmental factors. Arch Dis Child 1988;63:473-8. 
27 Weitzman M, Gortmaker S, Walker DR, Sobol A. Materna moking and childhood asthma. Pediatrics 1990;85:50511.

28 Young S, le Soeuf PN, Geelhoed GC, Stick SM, Turner $\mathrm{KJ}$, Landau LI. The influence of a family history of asthma and parental smoking on airway responsiveness in early infancy. $N$ Engl $f$ Med 1991;324:1168-73.

29 Braun-Fahrlander C, Ackermann-Leibrich U, Schwartz I Gnehm PG, Rutishauser M, Wanner HU. Air pollution and respiratory symptoms in pre-school children. Am Rev Respir Dis 1992;145:42-7.

30 Martinez FD, Cline M, Burrows B. Increased incidence of asthma in children of smoking mothers. Pediatrics 1992;89:21-6.

31 Central Statistical Office. Social trends 21. London: HMSO, 1991:121.

32 Kaplan BA, Mascie-Taylor CG. Biosocial factors in the epidemiology of childhood asthma in a British national epidemiology of childhood asthma in a British nationa

33 Wald N, Kiryluk S, Darby S, Doll R, Pike M, Peto R. UK smoking statistics. Oxford: Oxford University Press, 1988:34-5.

34 Peat JK, Britton WJ, Salome CM, Woolcock AJ. Bronchia hyperresponsiveness in two populations of Australian schoolchildren. III. Effect of exposure to environmental allergens. Clin Allergy 1987;17:297-300.

35 Platts-Mills TAE, de Weck AL. Dust mite allergens and asthma: a worldwide problem. $\mathcal{f}$ Allergy Clin Immunol 1989;83:416-27.

36 Sporik R, Holgate ST, Platts-Mills TAE, Cogswell JJ. Exposure to house-dust mite allergen (Der $p \mathrm{I})$ and the development of

37 Ellul-Micallef $\mathrm{R}$, Al-Ali S. The spectrum of bronchial asthma in Kuwait. Clin Allergy 1984;14:509-17.

38 Sesay HR, Dobson RM. Studies on the mite fauna of house dust in Scotland, with special reference to that of bedding. Acarologia 1972;14:384-92.

39 Rao VRM, Dean BV, Seaton A, Williams DA. A comparison of mite populations in mattress dust from hospital and from private houses in Cardiff, Wales. Clin Allergy $1975 ; 5: 209-15$

40 Central Statistical Office. Family expenditure data. London: HMSO, Time series 1965-91.

41 Ministry of Agriculture, Fisheries and Food. Household Food Consumption and Expenditure. Annual Reports of the National Food Survey Committee. London: HMSO, 1961-90.

42 Duthie GG, Shortt CT, Robertson JD, Walker KA, Arthur JR. Plasma antioxidants, indices of lipid peroxidation and coronary heart disease risk factors in a Scottish populacoronary heart disease risk factors in

43 Bolton-Smith C, Smith WCS, Woodward M, TunstallPedoe $H$. Nutrient intakes of different social class groups: results from the Scottish Heart Health Study (SHHS). $\mathrm{Br}$ f Nutr 1991;65:321-35.

44 Barnes PJ. New concepts in asthma and the implications for therapy. In: Mitchell DM, ed. Recent advances in respiracory medicine 5. Edinburgh: Churchill-Livingstone, 1991:45-60.

45 Molfino NA, Slutsky AS, Zamel N. The effects of air pollution on allergic bronchial responsiveness. Clin Exp pollution on allergic bronc

46 Ishizaki T, Koizumi K, Ikemori R, Ishiyama Y, Kushibiki E. Studies of prevalence of Japanese cedar pollinosis among the residents in a densely cultivated area. Ann Allergy 1987;58:265-70.

47 Sandstrom T, Stjernberg N, Andersson M-C, KolmodinHedman B, Lundgren R, Rosenhall L, et al. Cell response in bronchoalveolar lavage fluid after exposure to sulfur dioxide: a time-response study. Am Rev Respir Dis 1989;140:1828-31.

48 Kerhl HR, Vincent LM, Kowalsky RJ, Horstman DH, O'Neill JJ, McCartney WH, et al. Ozone exposure increases respiratory epithelial permeability in humans. $A m$ Rev Respir Dis 1987;135:1124-8.

49 Heffner JE, Repine JE. Pulmonary strategies of antioxidan defense. Am Rev Respir Dis 1989;140:531-54.

50 Stone J, Hinks LJ, Beasley R, Holgate ST, Clayton BA. Reduced selenium status of patients with asthma. Clin Sci 1989;77:495-500.

51 Flatt A, Pearce N, Thomson CD, Sears MR, Robinson MF Beasley R. Reduced selenium in asthmatic subjects in New Zealand. Thorax 1990;45:95-9.

52 Strachan DP, Cox BD, Erzinclioglu SW, Walters DE Whichelow MJ. Ventilatory function and winter fresh fruit consumption in a random sample of British adults Thorax 1991;46:624-9.

53 Britton J, Pavord I, Richards K, Knox A, Wahedna I, Wisniewski A, et al. The effects of dietary antioxidants on lung function in the general population. Am Rev Respir Dis 1993;147:A369.

54 Burney PGJ. A diet rich in sodium may potentiate asthma: epidemiological evidence for a new hypothesis. Chest 1987;91(Suppl):143S-148S.

55 Chatham MD, Eppler JH, Sauder LR, Green D, Kulle TJ Evaluation of the effects of vitamin $\mathrm{C}$ on ozone-induced Evaluation of the effects of vitamin $\mathrm{C}$ on ozone-induced
bronchoconstriction in normal subjects. Ann NY Acad Sci 1987;498:269-79.

56 Mohsenin V. Effect of vitamin $\mathrm{C}$ on $\mathrm{NO}_{2}$ induced airway responsiveness in normal subjects. A randomized double blind experiment. Am Rev Respir Dis 1987;136:1408-11.

57 Zuskin $\mathrm{E}$, Lewis AJ, Bouhuys A. Inhibition of histamineinduced airway constriction by ascorbic acid. 7 Allergy Clin Immunol 1975;51:218-26.

58 Mohsenin V, DuBois AB, Douglas JS. Effect of ascorbic acid on response to metacholine in asthmatic subjects. $\mathrm{Am}$ Rev Respir Dis 1983;127:143-7. 